\title{
GEOSPATIAL TECHNOLOGY BASED SOIL LOSS ESTIMATION FOR SUSTAINABLE URBAN DEVELOPMENT OF BUTWAL SUBMETROPOLITAN CITY, NEPAL
}

\author{
Umesh K. Mandal ${ }^{1}$ and Kabita Kumari ${ }^{2}$ \\ ${ }^{1}$ Research Directorate, Rector's Office, Tribhuvan University, Kathmandu, Nepal, \\ umeshmandal@ tribhuvan-university.edu.np \\ ${ }^{2}$ Associated to Bernhardt \& Arniko College, Kathmandu Nepal, kabitamandal2033@gmail.com
}

Technical Commission-III, WG-1

Key Words: Potential and Actual Soil Erosion, Land Use, Land Cover, Soil Survey, Ecological Degradation

\begin{abstract}
Geo-spatial technology was attempted to estimate the potential and actual soil loss and its correlative interpretation with physiographic soil units and land use and cover types in Butwal sub-metropolitan city, Central Region of Nepal. Among several empirical and physically based soil erosion models, widely used RKLS and RKLSCP, Revised Universal Soil Loss Equation (RUSLE) were employed to estimate the potential and actual soil loss in the present investigation, respectively. Five years of rainfall, topographic contour-spot height and soil map were basically used as source of information for in-depth investigation. Butwal sub-metropolitan located at foothill of Chure/Siwalik range was found highly sensitive or prone to soil erosion. A total of 32.68 and 1.83 million tons soil was potentially and actually estimated annually being lost from the city. Erosion rates were found highly correlated with the slope of physiographic soil unit. $60.93 \%$ of the total potential soil loss was mainly contributed only by physiographic-soil unit 12 with the spatial extent of $34.10 \%$ of the city area. This unit was characterized by steeply to very steeply sloping mountainous terrain having dominant slope greater than $30^{\circ}$ and loamy skeletal as dominant soil texture. Significant difference was found in the estimation of RKLS and RKLSCP indicating the substantial reduction contribution of soil loss by land use/cover types predominated by forest. after agriculture. Thus physiographic-soil unit 12 having soil loss highest must be given higher priorities for soil conservation and optimum urban land use planning required for sustainable urban development. Lower percentage of actual soil to the potential loss indicated the fact of contribution of cover management and erosional control practice factor in reducing soil erosion in existing situation.
\end{abstract}

\section{INTRODUCTION}

Land degradation in South Asia including Nepal costs US\$10 billion annually as a result of losses resulting from land degradation and that was equivalent to $2 \%$ of the countries' Gross Domestic Product, or $7 \%$ of the value of its agricultural output. And this high enough figure is a gross underestimate, since it measures only the on-site effects- reduced agricultural production whilst leaving out off-site effects- river silting, floods, landslides and road collapses (FAO, UNDP \& UNEP, 1994).

As on-site effects of soil erosion are the loss of soil from a field, the breakdown of soil structure and the decline in organic matter and nutrient result in a reduction of cultivable soil depth and a decline in soil fertility along with reduction of available soil moisture, resulting in more drought-prone conditions. The net effect is a loss of productivity resulting increased expenditure on fertilizers to maintain yields and ultimately leads to the abandonment of land, with consequences for food production and food security and a substantial decline in land value (Morgan , 2005).

As off-site consequences of erosion are sedimentation downstream or downwind reducing the capacity of rivers and drainage ditches, enhancing the risk of flooding, blocking irrigation canals and shortening the design life of reservoirs and ruining hydroelectricity and irrigation projects, increasing the levels of nitrogen and phosphorus in water bodies through the absorbing chemicals Erosion leads to the breakdown of soil aggregates and clods into their primary particles of clay, silt and sand. Through this process, the carbon that is held within the clays and the soil organic content is released into the atmosphere as $\mathrm{CO}_{2}$. Erosion is therefore a contributor to climatic change, since increasing the carbon dioxide content of the atmosphere enhances the greenhouse effect. (Morgan, 2005 and Lal, 1995)

In Nepal, more than $80 \%$ terrain is rugged and characterized by unstable and steep slopes making it vulnerable to exogenous factors, landslide and soil erosion (UNEP, 2001).Topsoil having highest level of nutrients is more productive for plant growth than lower horizons. Top soil erosion is threatening the soil fertility of many rainfed agricultural fields in the middle mountains of Nepal (Nakarmi and Shah, 2000).Nepal is severely affected by water erosion on their rainfed lands by soil fertility decline, and by deforestation and in parts of the hill and mountain areas, deforestation and water erosion have reached an extreme degree and $26 \%$ of agriculture land is degraded due to soil erosion (FAO, UNDP and UNEP, 1994).

As on site effects of soil erosion in Nepal, $13 \%$ of land area has deteriorated seriously and $10,000 \mathrm{~km}^{2}$ are devoid of sufficient vegetation leading to desertification process (Nelson, 1980) and about 1.3 million tons of plant nutrients estimated being removed by soil erosion process (Joshi et al. 1997).Similarly with respect to off site consequences, raising riverbeds in the Tarai at an estimated annual rate of $15-30, \mathrm{~cm}$, increasing the incidence of floods and reducing the fertility of fertile lands, damaging irrigation channels, dams and hydropower projects are results due to loss of top soil from the mountain. It Soil loss from cultivated and grazing land is a major factor in decline of soil fertility.

As Nepal is in the lines of world's Era of rapid urbanization, where more than half of the country's population is living in the urban areas and still under the process of forming more new municipalities Butwal sub-metropolitan city cannot escape from 
the addressing of the 2030 Agenda for Sustainable Development Goals in which SDG 11 focuses urban areas to make cities sustainable since the future of the nation relies in its sustainable urban development (MoUD (2017). For achieving this goal of making city sustainable, knowledge and understanding of soil erosion process and its annual estimation is foremost for the urban development authority.

The most common models used in Nepal are Morgan et al. (1984) in Middle Mountain (Shrestha, 1997), RUSLE in Bhote Koshi catchment, Nepal Himalaya (Andermann and Gloaguen, 2009), RUSLE and RMMF in Kalchi Khola in mountainous watershed. Beside this, USLE was successfully applied to assess soil erosion in Trijuga, Kulekhani, Pakhribas, Hamsingha Watersheds of Nepal by Sah, Kharel, Sherchan and Dhungana, respectively, with satisfactory results (Sah 1996; Kharel 1999; Sherchan 1991; Dhungana, 2002 cited in Jha and Paudel 2010). All these models in Nepal are applied in watershed basis rather than urban areas or cities or municipalities

Even though, a number of parametric models for estimating soil loss exist, this study focuses on the comparison of estimation of potential (RKLS) and actual soil loss by the application of Revised Universal Soil Loss Equation (RUSLE) based on the integration of Geospatial Technology for Butwal Submetropolitan city of Nepal.

\section{MATERIALS AND METHODS}

\subsection{Study Area}

Butwal was designated as municipality in 1959 , and located in the confluence of the two prominent national highways viz. Mahendra highway and Siddhartha highway linking to the hills and mountains in the north long ago. Butwal was officially declared as sub-metropolitan city on 2 December 2014 by combining two neighboring VDCs Motipur and Semlar (AFPN, 2017) Butwal sub-metropolitan city is one of the oldest municipalities of Nepal. Long established as a livable city of the nation, the development of the city initiated in a way along with the declaration of sub-metropolitan, the development is rapid growing.

The total geographic area covered is $101.58 \mathrm{~km}^{2}$ (10158.24 ha). Geometrically, the location of the study area ranges from $83^{\circ} 21^{\prime} 49.15^{\prime \prime} \mathrm{E}$ to $83^{\circ} 30^{\prime} 21.40^{\prime \prime} \mathrm{E}$ and $27^{\circ}$ $36^{\prime} 54.33 " \mathrm{~N}$ to $27^{\circ} 44^{\prime} 56.85^{\prime \prime} \mathrm{N}$. It is bounded by Tinau Gaunpalika of Palpa district in north and Sudhadhodhan Gaunpalika in south and Sainamaina Nagarpalika in the west and Tilotama and Devdaha Nagarpalika in the east. The lower part of the study area belongs to ward no-16 (119 m from $\mathrm{msl})$ where as upper part of ward no-12 (836 $\mathrm{m}$ from msl).The study area falls within 6 topo sheets viz 098-9,098-11,098$12,098-13,098-15$ and $098-16$ having the scale at 1:25,000. The climate is subtropical monsoon type. Daily mean monthly temperature ranges from $17.0^{\circ} \mathrm{C}$ to $31.40^{\circ} \mathrm{C}$ with average of $25.90^{\circ} \mathrm{C}$. .Maximum absolute temperature reaches to $42.50^{\circ} \mathrm{C}$ and the minimum absolute remains $7.50^{\circ} \mathrm{C}$. The annual precipitation is about $2600 \mathrm{~mm}$. Geologically, the study area consists of quaternary alluvium and deep weathered materials. The land unit consists of present river channel, sand, gravel bars and steeply to very steeply mountainous terrain. Physiographically, the study area is characterized by Terai plain and middle mountain slopping terrain. Tinau and Dana and are major rivers of this sub-metropolitan city along with tributaries- Suili, Satgadhi and Rajpur khola etc. At higher elevations, land cover is mixed forest which mainly consists of Sal (Shorea robusta) and sakhuwa and crops include rice, wheat and maize. The location of study area is shown in Figure. 1.

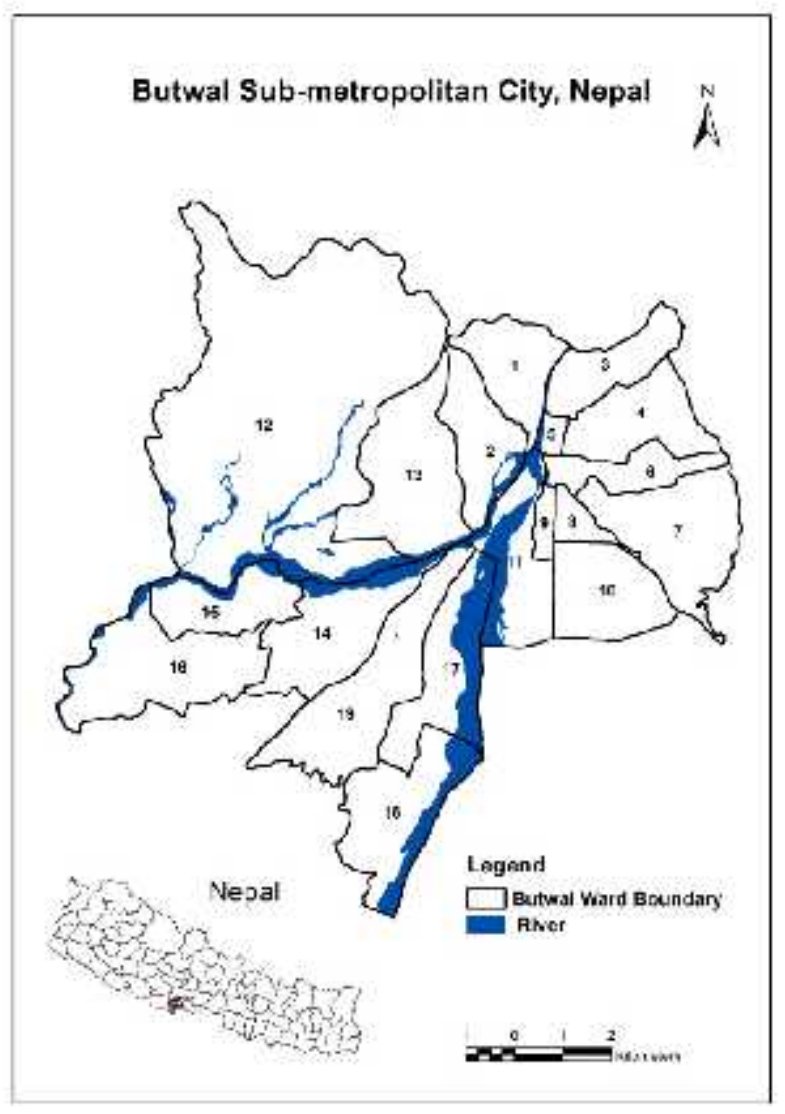

Figure 1: Location map of study area

\subsection{Methodology and Conceptual Framework}

Erosive rainfall, vegetation cover, soil erodibility, topography and protection measures are determining factors for estimation of soil loss. In the last decade, empirical, conceptual or physically based models have been evolved including former models of USLE (Wischmeier and Smith 1958, 1978). MUSLE (Williams and Berndt, 1977), SLEMSA (Stocking 1981), Morgan et al. (1984), RUSLE (Renard et al. 1997; SWCS, 1993) and latter models of WEPP (Flanagan et al. 2001), EUROSEM (Morgan et al. 1998) were models used in order to quantify the process of detachment, transport and deposition of eroded soil with the aim of implementing soil conservation strategy for sustainable watershed management and planning.

USLE developed by Wischmeier and others with USDA, ARS and SCS in late 1950 and revised in 1978 is a powerful tool widely used by soil conservationists in the United States and many other countries. Wise use of prediction technology requires the user be aware of a procedure's limitations. The USLE/RUSLE is an equation of estimating average annual soil loss by sheet and rill erosion on those portions where erosion, but not deposition is occurring. It does not estimate deposition at the toe of concave slopes, and not estimate sediment yield at a downstream location by not including ephemeral gully erosion. It also does not represent fundamental hydrologic and erosion processes explicitly 
(Renard et al.1997). The application of USLE/RUSLE as a tool to assist soil conservationists in farm planning by estimate of soil loss on specific slopes in specific fields. Thus, the USLE/RUSLE helps to tailor erosion control practices to those specific sites where soil loss exceed acceptable limits and then it guides the conservationist and farmer in choosing a appropriate practices controlling erosion adequately while meeting the needs and wishes of the farmer.

The conceptual framework and the six major parameters associated with the soil loss estimation are shown in Figure. 2 , and its explanation has been given below.

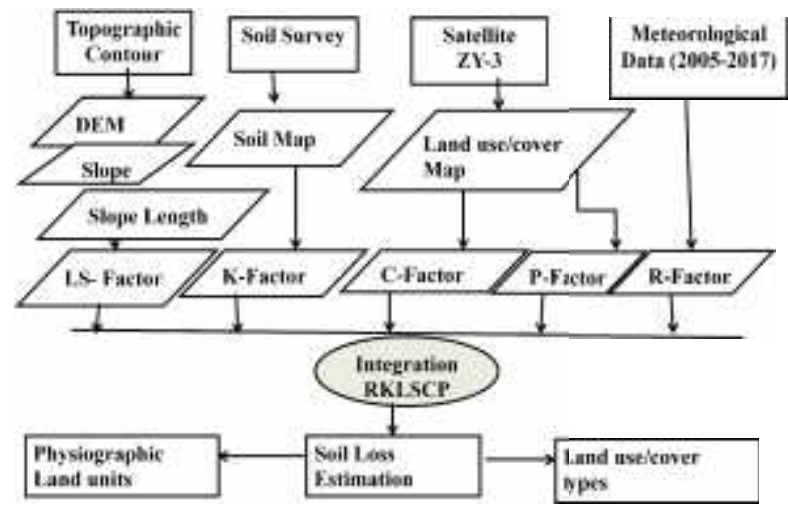

Figure 2. Conceptual framework for soil loss estimation

\subsubsection{Rainfall Erossivity}

Rainfall is essential for plant development, biomass and agriculture but it also is the driving force for soil erosion processes through detachment of soil particles and formation of surface runoff (Nyssen et al., 2005). Soil loss is related to kinetic energy of rainfall through the detachment power of raindrops striking the soil surface and the entrainment of the detached soil particles by runoff water down slope. The kinetic energy of rainfall is dependent on annual rain and rainfall intensity. For annual rain, rainfall data were collected during five years period (2013-2017) of fourteen stations located inside and the vicinity of Butwal sub-metropolitan city. Ensuring that no rain shadow area exists in the study area, a regression analysis of annual rainfalls with different elevations can be performed and if the correlation coefficient is found to be significant and high enough, an equation can be derived to compute rainfall map from elevation data (Morgan 1986; Morgan et al. 1984). Ten meter contour intervals and spot height from a topo- graphic base map was used to generate digital elevation model (DEM) by inter- polation procedure.

In the study area, significant correlation coefficient at $98 \%$ confidence level was found between annual rainfall (E) and elevation $(r=0.75)$ and thus used to generate a rainfall map using regression equation as follows:

\section{$\mathrm{E}=\mathbf{1 7 7 5}+\mathbf{0 . 3 6} * \mathrm{DEM}$}

Rainfall erosivity factor (R) is based on kinetic energy considerations of falling rain and represents a measure of the erosive force and intensity of rain in a normal year (Goldman et al. 1986). Two components of the factor are the total energy (E) and the maximum 30-min intensity of storms I30 (Wischmeier and Smith, 1978). The R factor is the sum of the product of these two components for all major storms in the area during an average year. Even though E and I30 are the most reliable source for computing $\mathrm{R}$, other equations might be used where $\mathrm{E}$ and $\mathrm{I} 30$ are not available. The equation $(\mathrm{R}=$ $38.5+0.35 \mathrm{P}$, where $\mathrm{P}$ represents mean annual precipitation) providing acceptable erossivity index for tropical and subtropical ecological zone is one of them (Eiumnoh, 2000). Other equations such as Equation 2 (Morgan, 2001) and Equation.3 (Renard and Freimund, 1994) are generally accepted equations for the mountainous sub-tropical climate.

$\mathrm{R}=(\mathbf{9 . 2 8} * \mathrm{P}-8838.15) * 0.102 * \mathrm{I30} / 173.6$

$\begin{array}{ll}R=0.0483 * P^{1.61} & P<850 \\ R=587.8-1.219 * P+0.00415 * P^{2} & P>850\end{array}$

Rainfall intensity is an essential component for assessing soil erosion, since splash detachment is a function of rainfall energy, soil detachability and rainfall interception by crops. Rainfall showers less than $12.5 \mathrm{~mm}$ in a given days are assumed too small to have practical significance and are not considered as erosive (Wischmeier and Smith, 1978). Considering the above mentioned fact, in this study, rainfall intensity has been used in the following equation for estimation of $\mathrm{R}$ factor:

$$
\mathrm{R}=E\left(11.87+8.73 \log _{10} I\right)
$$

where $\mathrm{R}=$ rainfall erossivity $(\mathrm{J} \mathrm{m}-2) \mathrm{E}=$ annual rainfall $(\mathrm{mm})$, $\mathrm{I}=$ rainfall intensity $(\mathrm{mm} / 1 \mathrm{hr})$ obtained from monthly rainfall interval $(\mathrm{mm})$ distribution and number of rainy days of each stations located in and around the Butwal sub-metropolitan city (Figure 3). Meteorological Stations used in this study has been shown in Table 1 and Figure 3.

Table 1. Rainfall station site characteristics

\begin{tabular}{|c|c|c|c|c|c|}
\hline $\begin{array}{l}\text { S. } \\
\text { No }\end{array}$ & Station name & $\begin{array}{l}\text { Index } \\
\text { No }\end{array}$ & $\begin{array}{l}\text { Lat N } \\
(\mathrm{deg} / \mathrm{min} \\
)\end{array}$ & $\begin{array}{l}\log E \\
(\operatorname{deg} / \min )\end{array}$ & $\begin{array}{l}\text { Ele.m( } \\
\text { amsl) }\end{array}$ \\
\hline 1 & Tansen & 702 & 2752 & 8332 & 1067.0 \\
\hline 2 & Butwal & 703 & 2742 & 8328 & 205.0 \\
\hline 3 & $\begin{array}{l}\text { Beluwa } \\
\text { (Girwari) }\end{array}$ & 704 & 2741 & 8403 & 150.0 \\
\hline 4 & $\begin{array}{l}\text { Bhairahawa } \\
\text { Airport }\end{array}$ & 705 & 2731 & 8326 & 109.0 \\
\hline 5 & $\begin{array}{l}\text { Bhairahawa } \\
\text { (Agric) }\end{array}$ & 707 & 2732 & 8328 & 120.0 \\
\hline 6 & Parasi & 708 & 2732 & 8340 & 125.0 \\
\hline 7 & Dumkiwas & 710 & 2735 & 8352 & 164.0 \\
\hline 8 & Khanchikot & 715 & 2756 & 8309 & 1760.0 \\
\hline 9 & Taulihawa & 716 & 2733 & 8304 & 94.0 \\
\hline 10 & $\begin{array}{l}\text { Patharkot } \\
\text { (West) }\end{array}$ & 721 & 2746 & 8303 & 200.0 \\
\hline 11 & Bhagwanpur & 723 & 2741 & 8248 & 80.0 \\
\hline 12 & Garakot & 726 & 2752 & 8348 & 500.0 \\
\hline 13 & $\begin{array}{l}\text { Lumbini } \\
\text { Mandir }\end{array}$ & 727 & 2728 & 8317 & 95.0 \\
\hline 14 & Simari & 728 & 2732 & 8345 & 154.0 \\
\hline
\end{tabular}

\subsubsection{Soil Erodibility}


Soil erodibility $(\mathrm{K})$ is defined as the inherent resistance of the soil to both detachment and transport. Although a soil's resistance to erosion depends in part on topographic position, slope steepness and the amount of disturbance such as during tillage, the properties of the soil are the most important determinants such as soil structure, organic matter content, soil texture and soil permeability, and it should be based on measured value wherever possible. These soil characteristics are parameters that can be obtained from soil profile descriptions, and $\mathrm{K}$ values were also estimated from soil erodibility nomograph for those cases silt fraction does not exceed $70 \%$ (Wichmeiser and Smith, 1978) derived from the equation:

$$
\begin{aligned}
& \mathrm{K}=2.1 * 10^{-6}\left(12-P_{\text {om }}\right) * f \mathrm{p}^{1.14}+0.0325(\mathrm{~S}-2)+0.025\left(f_{\text {perm }}-3\right) \\
& \text { in which } f \mathrm{p}=P_{\text {silt }}\left(100-P_{\text {clay }}\right)
\end{aligned}
$$

Where $\mathrm{P}_{\mathrm{Om}}$ is the percent organic matter, $\mathrm{f}_{\mathrm{p}}$ is the particle size parameter, $S$ is the soil structure index, $f_{\text {perm is }}$ the profilepermeability class factor, $\mathrm{P}_{\text {silt }}$ is the percent silt and $\mathrm{P}_{\text {clay }}$ is the percent clay. The $\mathrm{K}$ value can be calculated with the use of nomograph, derived by Wischemier and Smith (1978), when all the values of $\mathrm{K}$ influencing factors are available. In this study area, the soil parameters used are based on the average values of the laboratory data from the soil samples obtained from Land System Report. The soil detachability index $(\mathrm{K})$ is based on the value suggested soil parameters in Morgan et al. (1982) and given in Table 2. In general terms, the less the proportion of sand or silt, the higher the organic matter content, the more developed the soil structure, and the higher infiltration rate, the less erodible the soil will be (LRMP 1986).

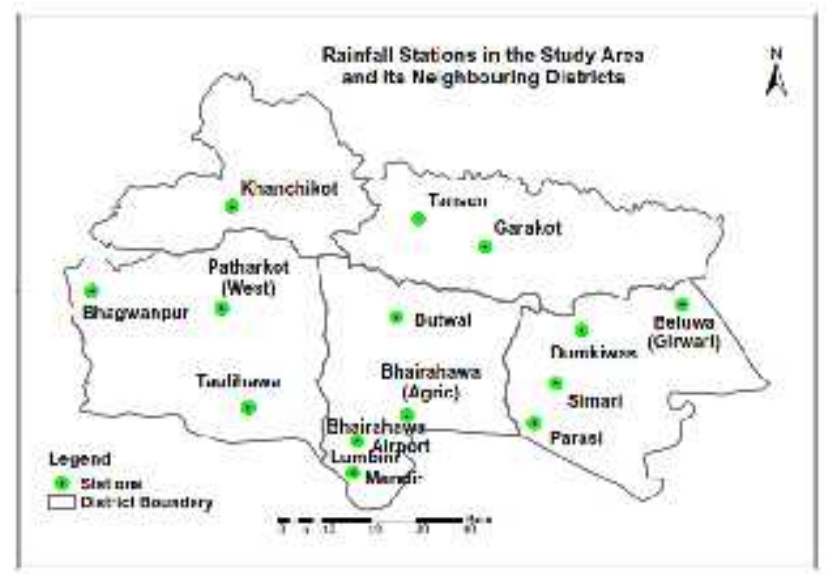

Figure 3. Rainfall station site characteristics

Soil map of Butwal sub-metropolitan city prepared by Topographic Survey and Land Use Management Division, Government of Nepal was used to calculate the soil erodibility $(\mathrm{K})$ factor by using the equation developed by Williams in 1995 (Neitsch, Arnold, Kiniry and Williams, 2000 and Williams 1995). Seventy-eight soil pits based on soil mapping units were taken evenly distributed across the city. A polygon attribute file of the physiographic soil map was used to generate $\mathrm{K}$ value map using relationship with soil texture. The equation used for estimating $\mathrm{K}_{\text {USLE }}$ is given below

$\mathrm{K}_{\mathrm{USLE}}=\mathrm{fcsand} * \mathrm{fcl}-\mathrm{si} *$ forgc $*$ fhisand

where: fcsand is a factor, that lowers the $\mathrm{K}$ indicator in soils with high coarse-sand content and higher for soils with little sand; fcl-si gives low soil erodibility factors for soils with high clay-to-silt ratios; forgc reduces $\mathrm{K}$ values in soils with high organic carbon content, while fhisand lowers $K$ vahues for soils with oxtremely high sand content:

$$
\begin{aligned}
& \text { fcsand }=\left[0.2+0.3 * \exp \left\{-0.256 * m_{s}\left(1-\frac{m_{\text {sitit }}}{100}\right)\right\}\right] \\
& f c l-s i=\left(\frac{m_{\text {silt }}}{m_{c}+m_{\text {sith }}}\right)^{0.3} \\
& \text { forgc }=\left\{1-\frac{0.25 * \text { orgC }}{\text { orgC }+\exp (3.72-2.95+\operatorname{org} C)}\right\} \\
& \quad \text { fhisand } \\
& \quad=\left[1-\frac{0.7+\left(1-\frac{m_{s}}{100}\right)}{\left(1-\frac{m_{s}}{100}\right)+\exp \left\{-5.51+22.9 *\left(1-\frac{m_{s}}{100}\right)\right\}}\right]
\end{aligned}
$$

where:

$\mathrm{m}_{\mathrm{s}}$ - the percent sand content $(0.05-2.00 \mathrm{~mm}$ diameter $)$ $\mathrm{m}_{\text {silt }}$ - the percent silt content $(0.002-0.05 \mathrm{~mm}$ diameter $)$ $\mathrm{m}_{\mathrm{c}}$ - the percent clay content $(<0.002 \mathrm{~mm}$ diameter $)$ orgC - the percent organic carbon content

\subsubsection{Topographic Factors: Slope Length and Steepness (LS)}

The potential for surface soil erosion will increase as the topographic factors, slope steepness and length are steeper and longer, respectively. The higher the velocity and greater the concentration of water, greater will be the erosion. Thus, the slope factors are key component for estimating soil erosion hazard. The factors of slope length (L) and slope steepness (S) are combined in a single topographic index termed as LS factor. Wischmeier and Smith defined the slope length as the distance from the point of origin of overland flow to the point where either the slope gradient decreases enough that deposition begins or the runoff water enters a well-defined channel that may be part of a drainage network or a constructed channel. Slope steepness in percentage for the present watershed was derived from digital elevation model $(\mathrm{DEM})$. Slope $=(\mathrm{hyp}(\mathrm{dx}, \mathrm{dy}) / \mathrm{pixel}$ size $) * 100$ and slope length was estimated by the relationship as: $\mathrm{L}=0.4 * \mathrm{~S}+40$.

The original USLE formula for estimating the LS factor was used for slope steepness up till $21 \%$. The equation is:

$\mathrm{LS}=(\mathrm{L} / 72.6) *(65.41 * \sin (\mathrm{S})+4.56 * \sin (\mathrm{S})+0.065)$

The Gaudasasmita equation given below was used for the slope steepness of $21 \%$ or more:

$\mathrm{LS}=(\mathrm{L} / 22.1)^{0.7} *\left(6.432 * \sin \left(\mathrm{S}^{0.79}\right) * \operatorname{Cos}(\mathrm{S})\right)$

Finally, topographic factor was generated by combing maps derived from Equation. 8 and 9

\subsubsection{Crop Management Factor (C)}

The crop management factor represents the ratio of soil loss under a given crop to that from bare soil. Since soil loss varies with the erossivity and the morphology of the plant cover. It 
varies from 1 on bare soil to $1 / 1000$ under forest, $1 / 100$ under grasslands and cover plants, and 1 to $9 / 10$ under root and tuber crops. Knowing the land use, its value can be simply obtained from published tables. So, in the simplest form, as in the USLE, the $\mathrm{C}$ factor is estimated based on the land use categorization of the concerned area. But in RUSLE, this factor is greatly revised and is estimated with the soil loss ratio (SLR) algorithm which incorporates several sub factors like prior-land-use (PLU), canopy-cover (CC), surface-cover (SC), surface-roughness (SR) and soil moisture (SM) (Renard et al.1991). Indirectly through the vegetation parameters like Normalized Difference Vegetation Index (NDVI) or Leaf Area Index (LAI) as used for estimation of $\mathrm{C}$ factor (Suriyaprasita and Shrestha, 2008), in order to determine $\mathrm{C}$ factor in Butwal sub-metropolitan city, supervised classified land use map generated from inte- grated use of ZY-3 satellite images (2018), aerial photographs and toposheets was used.

Table 2. Crop management factor for agriculture

\begin{tabular}{lrrll}
\hline $\begin{array}{l}\text { Mon } \\
\text { ths }\end{array}$ & $\begin{array}{l}\text { Adjusted R factor } \\
\text { (\% R value) }\end{array}$ & $\begin{array}{l}\text { C } \\
\text { value } \\
*\end{array}$ & $\begin{array}{l}\text { cropping } \\
\text { pattern }\end{array}$ & $\begin{array}{l}\text { weighted C } \\
\text { factor }\end{array}$ \\
\hline Jan & 0.63 & 0.6 & Wheat & 0.0038 \\
Feb & 0.65 & 0.5 & Wheat & 0.0032 \\
Mar & 0.23 & 0.4 & Wheat & 0.0009 \\
Apr & 0.87 & 0.7 & Wheat & 0.0061 \\
May & 6.29 & 0.1 & Maize & 0.0063 \\
Jun & 17.36 & 0.9 & Paddy & 0.1563 \\
Jul & 30.22 & 0.6 & Paddy & 0.1813 \\
Aug & 25.90 & 0.5 & Paddy & 0.1295 \\
Sep & 14.97 & 0.4 & Paddy & 0.0599 \\
Oct & 2.58 & 0.6 & Paddy & 0.0155 \\
Nov & 0.16 & 0.7 & Paddy & 0.0011 \\
Dec & 0.14 & 0.9 & Wheat & 0.0012 \\
& Weighted C factor for agriculture & 0.5651 \\
\hline
\end{tabular}

\section{- $\quad$ Morgan,2005}

$\mathrm{C}$ values used in this analysis were defined 0.004 for dense mixed sal forests, 0.02 for bush land and grass lands, 1 for bare land and 0.56 for agriculture,. It is necessary to take account of changes in the cropping pattern during the year in arriving at an annual value including rainfall distribution (Morgan 2005 \& Roose, 1975).Paddy is being planted from June to November, wheat is from December to April and Maize is from May to July of the year in Butwal areas of Nepal.

Of the mean annual precipitation during the period 2013-2017, 30 percent falls in July, 25 percent in August, 17 percent in June, 6 percent in May and 14 percent in September. Considering that erosivity is directly related to precipitation amount, these values can be used to describe the weighted crop management factor (C) for agriculture and Table 2 has been constructed.

\subsubsection{Erosion Control Practice Factor (P)}

The erosion-control practice factor is obtained from tables of the ratio of soil loss where the practice is applied to the soil loss where it is not.. Values cover contouring and contour stripcropping and vary with the slope steep The factor mainly represents how surface conditions affecting flow paths and flow hydraulics. This factor is a ratio between erosion occurring in a field treated with conservation measures and another reference plot without treatment. Therefore, erosion control practice factor is based on the soil conservation practices such as contouring operated in a particular area. Details of procedure of calculation are obtained from Agricultural Handbook 703 (Renard et al. 1997). But practically, the data of the adopted erosion control practices in the agricultural area are, in general, ranging from 1 for non-agriculture assuming that no conservation measures are implemented to 0.5 for agriculture land and its further redistribution spatially among different slope categories: 0.1 for $0-5 \%$ to 0.33 for $50-100 \%$ (Wischmeier and Smith, 1978) and accordingly, P value map was generated.

\section{RESULTS AND DISCUSSIONS}

\subsection{Potential and Actual Soil Loss Estimation in Butwal Sub-metropolitan City}

Scientific planning for soil and water conservation requires the knowledge of factors that causes the soil loss and reduces it (Wischmeier \& Smith, 1978). Potential soil loss has been considered as the erosion susceptibility derived from rain erossivity, soil erodibility and the factor slope with ought taken into account the crop cover and erosion control management practices (Toxopeus, 1997) Similarly, actual soil loss was conceptualized considering the natural occurring factors estimated from RUSLE equation. In this line, the results of soil loss estimation derived from RKLS representing as potential and RUSLE as actual soil loss model in Butwal sub metropolitan city were presented and discussed in two ways of analysis units: physiographic land units and land use and cover types as below.

Table 3.Spatial extent of potential and actual soil loss estimation

\begin{tabular}{lcccc}
\hline \multirow{2}{*}{$\begin{array}{c}\text { soil loss classes } \\
\text { (t/ha/yr })\end{array}$} & \multicolumn{2}{c}{ Potential } & \multicolumn{2}{c}{ Actual } \\
\cline { 2 - 5 }$<2$ & Area(ha) & $\%$ & Area(ha) & $\%$ \\
$2-5$ & 0.00 & 0.00 & 295.75 & 2.91 \\
$5-10$ & 0.00 & 0.00 & 466.14 & 4.59 \\
$10-50$ & 0.00 & 0.00 & 398.27 & 3.92 \\
$50-100$ & 0.00 & 0.00 & 4240.31 & 41.74 \\
$100-500$ & 96.76 & 0.95 & 547.55 & 5.39 \\
$>500$ & 352.64 & 3.47 & 3447.72 & 33.94 \\
Total & 9708.84 & 95.58 & 762.49 & 7.51 \\
\hline
\end{tabular}

Based on the erosion rates, the study area was classified into seven erosion classes ranging from 69 to 31,287 tons/ha/year as of potential and 0.0009 to 12,513 tons/ha/year for actual soil loss. As compared to potential soil loss, $95.58 \%$ of city area is fallen within the highest category of class with erosion rates greater than 500 tons/ha/year( Table 3 and Figure 5), whereas only $7.51 \%$ of city area is found under the same category in case of actual soil loss estimation (Table 3 and Figure 4 ). Implication of spatial distribution of such rate shown in Figure 4 indicates that land cover as forest, bush, shrub and grass present in the natural condition in the northern 
part of city has positive factors to reduce the soil loss. There is significant variation found in geographic area distribution of city in both situations as potential and actual estimation.

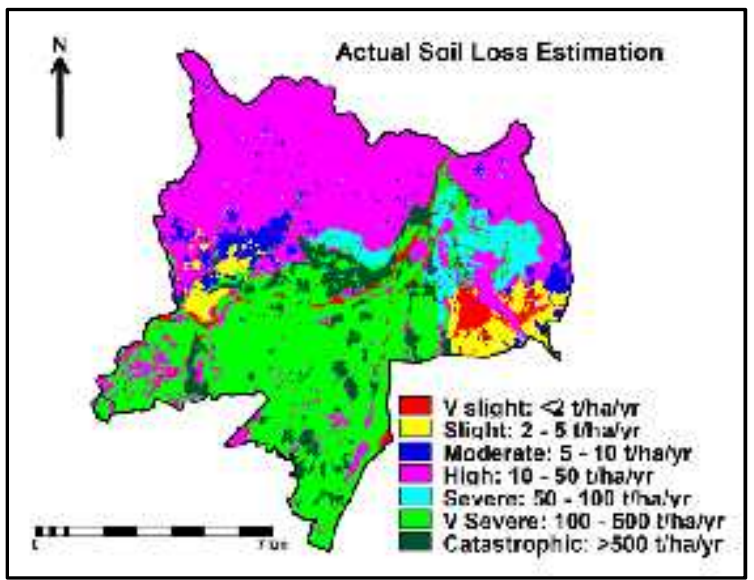

Figure 4. Actual soil loss estimation

A total of 32.68 million ton/ha/yr is estimated as potential soil loss using RKLS annually being lost from the city. In the natural condition, a total of 1.83 million ton/ha/yr is estimated as actual soil loss using RUSLE model representing $5.60 \%$ of potential soil loss (Table 3). The mean annual soil loss estimated as potential in the study area was found to be 3.27 million ton/ha/yr and 0.18 million ton/ha/yr as actual soil loss (Table 3 ) that is seemed more in Terai as compared to Hill (Mandal et al. 2015).

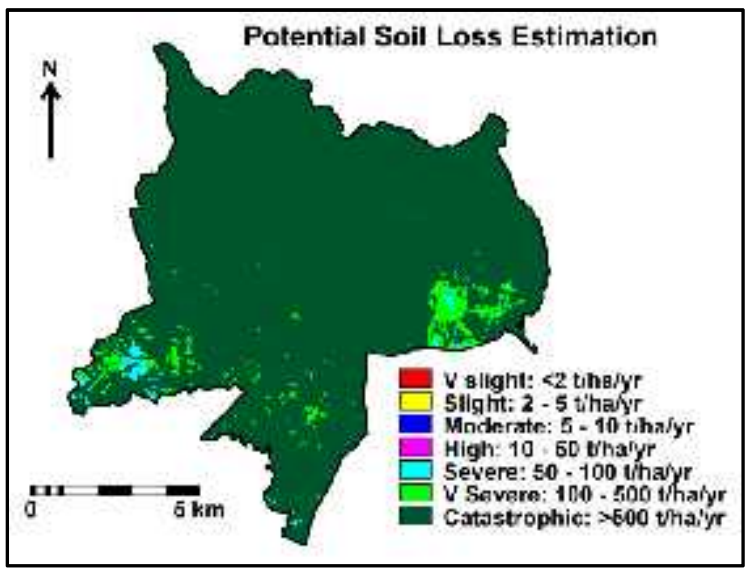

Figure 5. Potential soil loss estimation

\subsection{Potential and Actual Soil Loss in Physiographic Soil Units}

Potential and actual soil losses in Butwal sub-metropolitan city were estimated by physiographic land units in order to understand the degree of influence and role of physiographic landforms in accelerating erosion. The spatial extent of potential and actual soil loss by physiographic land units is given in Table 4.

Erosion rates were found highly correlated with the increasing slope of land units in both situations: potential and actual. It was evident by the fact that land unit such as 12 having degree of slope more than $30^{\circ}$ was found with highest potential (19.91 million ton/ha/yr) soil loss representing $60.93 \%$ of total potential soil loss in the city (Table 4 ). Similarly, in the case of actual soil loss estimation, same land unit 12 contributes less (0.16 million ton/ha/yr) than potential soil loss representing $8.83 \%$ of total actual soil loss. Such reduction of soil loss was contributed by the presence of land cover particularly forest. Such land unit was characterized by lithic ustorthents as dominant soil and loamy skeletal as the dominant soil texture. Both modelsRKLS and RKLSCP was found significantly difference in terms of average soil loss estimation at $99 \%$ of confidence interval. It was evident from the reduced value of 0.18 in RKLS than 3.27 in RKLSCP (Table 4.0)

Table 4. Potential and actual soil loss by physiographic soil units

\begin{tabular}{|c|c|c|c|c|c|c|}
\hline \multirow{2}{*}{$\begin{array}{l}\text { Physiog } \\
\text { raphic } \\
\text { soil } \\
\text { units* }\end{array}$} & \multirow[t]{2}{*}{$\begin{array}{c}\text { Area } \\
\text { (ha \%) }\end{array}$} & \multicolumn{4}{|c|}{$\begin{array}{l}\text { Total soil loss estimation } \\
\text { (Millian ton/ha/yr) and their } \\
\text { percentage }\end{array}$} & \multirow{2}{*}{$\begin{array}{c}\% \text { of } \\
\text { actual } \\
\text { to } \\
\text { potent } \\
\text { ial }\end{array}$} \\
\hline & & $\begin{array}{c}\text { Poten } \\
\text { tial }\end{array}$ & $\%$ & Actual & $\%$ & \\
\hline $1 \mathrm{ab}$ & 8.17 & 1.24 & 3.79 & 0.18 & 9.83 & 14.52 \\
\hline $1 \mathrm{c}$ & 1.66 & 0.17 & 0.52 & 0.04 & 1.96 & 21.16 \\
\hline $2 b$ & 3.57 & 0.26 & 0.79 & 0.10 & 5.33 & 37.50 \\
\hline $2 \mathrm{c}$ & 30.80 & 3.41 & 10.45 & 1.09 & 59.68 & 32.04 \\
\hline $2 d$ & 0.27 & 0.02 & 0.07 & 0.01 & 0.42 & 38.87 \\
\hline $3 a$ & 6.00 & 0.93 & 2.84 & 0.04 & 2.35 & 4.63 \\
\hline $3 b$ & 6.20 & 2.57 & 7.86 & 0.10 & 5.65 & 4.02 \\
\hline $3 c$ & 5.38 & 1.88 & 5.76 & 0.10 & 5.29 & 5.15 \\
\hline $3 d$ & 3.85 & 2.29 & 6.99 & 0.01 & 0.65 & 0.52 \\
\hline 12 & 34.10 & 19.91 & 60.93 & 0.16 & 8.83 & 0.81 \\
\hline Total & 100.00 & 32.68 & $\begin{array}{c}100.0 \\
0\end{array}$ & 1.83 & $\begin{array}{c}100.0 \\
0\end{array}$ & 5.60 \\
\hline Average & 10.00 & 3.27 & & 0.18 & & \\
\hline
\end{tabular}

* Active river channel and sand-gravel bars(1ab),Former channels-low terrace(1c),Recent alluvial plain-intermediate position-level( $2 b)$, intermediate position-undulating (2c), high position(2d),Alluvial fan-very gentle slopes( $3 a)$,gentle slopes(3b), undulating $(3 c)$ and highly dissected (3d) ,Steeply to very steeply sloping mountainous terrain(12).

\subsection{Potential and Actual Soil Loss in Land Use/Cover Types}

Potential and actual soil losses in Butwal sub-metropolitan were estimated by land use and cover types in order to understand its role in determining erosion rate. The potential and actual soil loss by land use and land cover types and its summary statistics are given in Table 5.0. Soil erosion rates were found highly correlated with the increasing exposure of land surface. Forest land use was found considerably highest proportion in terms of coverage $(44.67 \%)$ and also in potential soil loss (23.26 million ton/ha/yr) representing highest share $(71.18 \%)$ in total potential soil loss. These figures were found moderate in the case of RKLSCP model indicating higher contributing factor for reducing soil loss. This story was found reverse in the case of agriculture land in RKLSCP model that shares $33.37 \%$ of total land use land cover in the city, was causal to highest contributor to the soil erosion (1.40 millian 
ton/ha/yr) representing almost $76.26 \%$ of the total actual soil loss.

After applying crop management (C factor) and erosion control practice ( $\mathrm{P}$ factor) in actual soil loss estimation, RUSLE, the scenario of erosion condition was quite opposite supporting the fact that agriculture land use was considered as most influencing factor. It was due to the fact that erosion control practice as forestry was relatively better than unmanaged agriculture practices. The figure of percentage of actual to potential soil loss depicted in last column of Table 4 and Table 5 indicates the higher contribution of crop management and erosion control practices with its decreasing value.

Table 5. Potential and actual soil loss by physiographic soil units

\begin{tabular}{|c|c|c|c|c|c|c|}
\hline \multirow{2}{*}{$\begin{array}{c}\text { Land } \\
\text { use/Land } \\
\text { cover types }\end{array}$} & \multirow{2}{*}{$\begin{array}{c}\text { Area } \\
\text { (ha } \\
\%)\end{array}$} & \multicolumn{4}{|c|}{$\begin{array}{l}\text { Total soil loss(Million } \\
\text { ton/ha/yr) }\end{array}$} & \multirow{2}{*}{$\begin{array}{l}\% \text { of } \\
\text { actual } \\
\text { to } \\
\text { potent } \\
\text { ial }\end{array}$} \\
\hline & & $\begin{array}{l}\text { Potenti } \\
\text { al }\end{array}$ & $\%$ & $\begin{array}{l}\text { Act } \\
\text { ual }\end{array}$ & $\%$ & \\
\hline Barren & 0.79 & 0.07 & 0.22 & 0.07 & 3.99 & 100.0 \\
\hline $\begin{array}{l}\text { Land } \\
\text { Built up } \\
\text { area }\end{array}$ & 4.10 & 1.03 & 3.15 & 0.04 & 2.25 & $\begin{array}{r}0 \\
4.00\end{array}$ \\
\hline Bush & 7.24 & 3.13 & 9.58 & 0.05 & 2.74 & 1.60 \\
\hline Cliff & 0.00 & 0.00 & 0.00 & 0.00 & 0.02 & 80.00 \\
\hline Cultivation & 33.37 & 3.84 & $\begin{array}{c}11.7 \\
4\end{array}$ & 1.40 & 76.26 & 36.40 \\
\hline Forest & 44.67 & 23.26 & $\begin{array}{c}71.1 \\
8\end{array}$ & 0.08 & 4.19 & 0.33 \\
\hline Nursery & 1.00 & 0.06 & 0.19 & 0.00 & 0.02 & 0.56 \\
\hline Orchard & 0.02 & 0.00 & 0.01 & 0.00 & 0.00 & 0.56 \\
\hline $\begin{array}{l}\text { Pond / } \\
\text { Lake }\end{array}$ & 0.09 & 0.01 & 0.03 & 0.00 & 0.09 & 15.76 \\
\hline Sand & 7.36 & 1.06 & 3.25 & 0.19 & 10.43 & 18.00 \\
\hline Swamp & 0.05 & 0.00 & 0.01 & 0.00 & 0.00 & 0.00 \\
\hline Water body & 1.31 & 0.21 & 0.63 & 0.00 & 0.00 & 0.00 \\
\hline Total & $\begin{array}{c}100.0 \\
0\end{array}$ & 32.68 & $\begin{array}{c}100 . \\
00\end{array}$ & 1.83 & $\begin{array}{r}100.0 \\
0\end{array}$ & 5.60 \\
\hline Average & 8.33 & 2.72 & 8.33 & 0.15 & 8.33 & 21.43 \\
\hline
\end{tabular}

\subsection{Prioritization for Sustainability of Urban Development}

After assessment of actual soil loss severity over the entire city area, it is essential to priorities the areas having high rate of soil erosion.

Table 6. Prioritization of areas for sustainable urban development

\begin{tabular}{lll}
\hline Severity of erosion rates & Class & Prioritization \\
\hline$<2 \mathrm{t} / \mathrm{ha} / \mathrm{yr}$ & Very slight & Low \\
$2-5 \mathrm{t} / \mathrm{ha} / \mathrm{yr}$ & Slight & Low \\
$5-10 \mathrm{t} / \mathrm{ha} / \mathrm{yr}$ & Moderate & Low \\
$10-50 \mathrm{t} / \mathrm{ha} / \mathrm{yr}$ & High & Low \\
$50-100 \mathrm{t} / \mathrm{ha} / \mathrm{yr}$ & Severe & Moderate \\
$100-500 \mathrm{t} / \mathrm{ha} / \mathrm{yr}$ & Very severe & High \\
$>500 \mathrm{t} / \mathrm{ha} / \mathrm{yr}$ & Catastrophic & Very high \\
\hline
\end{tabular}

In this context, Table 6 shows the priorities areas where high rate of soil erosion estimated were observed. These areas are spatially concentrated in southern part of city are particularly Motipur and Semlar VDC latter added to this municipality to become Sub-metropolitan city.

These areas are having agriculture practices without proper crop management and erosion control mechanism that are to be given high attention for downstream Tinau watershed conservation and also for urban agriculture development in downstream. Based on severity of soil loss, steeply to very steeply sloping mountainous terrain areas are also to be given priority with reforestation management practices for reducing soil loss. Soil conservation measures are to be adopted on more traditional insensitive farming required for sustainable urban development planning.

\section{CONCLUSIONS}

A total of 32.68 and 1.83 million ton/ha/yr soils were estimated using RKLS and RUSLE annually being lost from the city , respectively. Similarly, significance difference was found in the mean annual soil loss estimated by potential and actual models for the study area. It was found 3.27 and 0.18 million ton/ha/yr for potential and actual respectively. In RKLS estimations, soil loss was found highly correlated with the increasing slope of land units. It was evident by the fact that land unit 12 having more than $30^{\circ}$ slope, was found to be 19.91 million ton/ha/yr soil loss representing $60.93 \%$ of total potential soil loss in the city that is characterized as lithic ustorthents as dominant soil type with loamy skeletal as dominant soil texture. Soil erosion rates were found highly correlated with the increasing cover of land surface. It was supported by the fact that forest covers $44.67 \%$ of the city area sharing $71.18 \%$ in total potential soil loss, was reduced to 4.19 $\%$ in actual soil loss. Cultivation areas sharing $33.37 \%$ of total land use land cover was contributing less in potential $(11.74 \%)$ and more $(76.26 \%)$ in actual soil loss estimation. It was due to adopting unscientific measures of agriculture practices. Steeply to very steeply sloping mountainous terrain including agriculture areas have to be given higher priorities for $\mathrm{urban}$ management and conservation planning. Lower percentage of actual to the potential soil loss indicated the fact of contribution of crop management and erosional control practice factor in reducing soil erosion in existing situation.

\section{References}

Andermann C, Gloagluen R 2009. Estimation of erosion in tectonically active orogenies. Example from the Bhotekoshi catchment, Himalaya (Nepal). Int J Remote Sens 30(12). (Taylor \& Francis, Inc. Bristol, PA, USA)

AFPN 2017. Diagnostic Study of Local Governance in Federal Nepal, The Asian Foundation in Nepal, Australian Aid

Eiumnoh A 2000. Integration of geographic information systems (GIS) and satellite remote sensing (SRS) for watershed management. Tech Bull 150. (Food \& Fertilizer Technology Center, Taiwan)

FAO, UNDP \& UNEP 1994. Land degradation in south Asia: Its severity, causes and effects upon the people World Soil Resources Reports Food and Agriculture Organization of The United Nations Rome, 
Flanagan DC, Ascough JC, Nearing MA, Laflen JM 2001. Chapter 8. Water erosion prediction project (WEPP) model. In: Harmon RS, Doe WW (eds) Landscape erosion and evolution modeling. Kluwer Academic Publishers, Norwell, M. A., p 54

Goldman SJ, Jackson K, Bursztynsky TA, 1986. Erosion and sediment control handbook. McGraw-Hill, New York

Jha MK, Paudel RC, 2010. Erosion predictions by empirical models in a mountainous watershed in Nepal. J Spat Hydrol 10(1). (Spring)

Joshi D, Pandey SP, Masky RB, 1997. Status of land degradation in Nepal

Lal, R. 1995. Global soil erosion by water and carbon dynamics. In Lal, R., Kimble, J.M., Levine, E. and Stewart, B.A. (eds), Soils and global change.CRC/Lewis, Boca Raton, FL: 131-41.

LRMP, 1986. Land system report: The soil landscape of Nepal. Resources Mapping Project, Kenting Earth Sciences limited, Ottawa, Canada

Mandal UK et al, 2015. Spatial soil erosion modeling for sustainable agriculture development using remote sensing. Dhaka Univ J Biol Sci 24(2):177-189

Morgan RPC, 2005. Soil erosion and conservation. Longman Third edition published, Blackwell Publishing Ltd, 350 Main Street, Malden, MA 02148-5020, USA, ISBN1-4051-1781-8

Morgan RPC, 1986. Soil erosion and conservation. Longman Scientific and Technical, England. ISBN 0-582-30158-0.298

Morgan RPC, 2001. A simple approach to soil loss prediction: a revised Morgan-Morgan-Finney model. CATENA 44:305-322

Morgan RPC, Morgan DDV, Finney HJ, 1982. Stability of agricultural ecosystems: documentation of a simple model for soil erosion assessment. International Institute for applied systems analysis collaborative paper CP-82-50

Morgan RPC, Morgan DDV, Finney HJ, 1984. A predictive model for the assessment of soil erosion risk. J Agric Eng Res $30: 245-253$

Morgan RPC, Quinton JN, Smith RE, Govers G, Poesen JWA, Auerswald K, Chisci G, Torri D, Styczen ME, 1998. The European Soil Erosion Model (EUROSEM): A dynamic approach for predicting sediment transport from fields and small catchments. Earth Surf Proc Land 23: 527-544

MoUD, 2017. National Urban Development Strategy (NUDS),Part A: Main Document, Government of Nepal, Ministry of Urban Development, Urban Development and Physical Planning Division, Kathmandu, Nepal

Nakarmi G, Shah PB, 2000. Soil nutrient losses through soil erosion in the middle hills of Nepal.In: Tripathi BP, Rajbhandari NP, Ransom JK (eds) Improved soil fertility management for sustainable maize production: proceedings of a workshop group meeting of the Hill Maize research project. Nepal Agricultural Research Council/HMRP/CIMMYT, Nepal

Neitsch S.L., Arnold J.G., Kiniry J.R., Williams J.R. 2000 Erosion Soil and Water Assessment Tool Theoretical
Documentation Texas Agricultural Eksperiment Station. pp. 625 ,

Nelson D. 1980. A reconnaissance inventory of the major ecological land units and their watershed condition-summary report. Dept of Soil Conservation and Watershed Management. UNDP, FAO FO: DP/NEP/74/020, Rome

Nyssen, J., Vandenreyken, H., Poesen, J., Moeyersons, J. Deckers, J., Haile, M., Salles, C.,Govers, G., 2005. Rainfall erosivity and variability in the northern Ethiopian highlands. J.Hydrol311:172-187.

http://dx.doi.org/10.1016/j.jhydrol.2004.12.016.

Renard KG, Freimund JR. 1994. Using monthly precipitation data to estimate the R-factor in the revised USLE. J Hydrol $157: 287-306$

Renard KG, Foster GR, Weesies GA, Porter JP, 1991. RUSLE: revised universal soil lossequation. J Soil Water Conserv 46:3033

Renard KG, Foster GR, Weesies GA, McCool DK, Yoder DC, 1997. Predicting soil erosion by water: a guide to conservation planning with the revised universal soil loss equation (RUSLE). USDA Agricultural handbook 703.

Roose, E.J. 1975. Erosion et ruissellement en Afrique de l'ouest: vingt années de mesures en petites parcelles expérimentales. ORSTOM, Adiopodoumé, Ivory Coast.

Shrestha, DP. 1997. Assessment of soil erosion in the Nepalese Himalaya, a case study in Likhu Khola Valley. Middle Mountain Region International Institute for Aerospace Survey and Earth Sciences (ITC) 7500 AA Enschede, The Netherlands

Stocking, M. 1981. A working model for the estimation of soil loss suitable for underdeveloped areas. Development studies, occasional paper No. 15, University of East Anglia, Norwich (UK)

Suriyaprasita M, Shrestha DP. 2008. Deriving land use and canopy cover factor from remote sensing and field data in inaccessible Mountainous Terrain for use in soil erosion modelling. The international archives of the photogrammetry, remote sensing and spatial information sciences, vol XXXVII. Part B7. Beijing

SWCS 1993. User's guide. Revised universal soil loss equation, version 1.03. Soil and Water Conservation Society, Iowa, USA

Toxopeus A, 1997. Cibodas: the erosion issue. In: I. ILWIS Department, ILWIS 2.1 for Windows, Applications Guide ILWIS Department, ITC, Enschede, Netherland, pp 289-309

UNEP 2001. Nepal: state of the environment. In: Collaboration with MoPE/HMGN,SACEP ICIMOD and NORAD, UNEPRegional Resource Center for Asia and Passific

Williams JR, Berndt HD, 1977. Sediment yield prediction based on watershed hydrology.Trans ASAE 1100-1104

Williams J.R. 1995. Chapter 25: The EPIC model. In V. P Singh (ed.) Computer models of watershed hydrology Water Resources Publications. p. 909-1000.

Wischmeier, W. H.,\& Smith, D.D. 1978. Predicting rainfal erosion loses: A guide to cortorvation planning. U.S Department of Agriculture, Agriculture Handbook No. 337. 